\title{
University Students' Perception toward Plagiarism
}

\author{
K.S.D. Darmayanti ${ }^{1}$, M.H. Santosa ${ }^{2}$, I.P.I. Kusuma ${ }^{3}$ \\ Jurusan Pendidikan Bahasa Inggris, Universitas Pendidikan Ganesha \\ Singaraja, Indonesia \\ E-mail; (setyadewikd@gmail.com, mhsantosa@undiksha.ac.id, indrakusuma.eed@gmail.com)
}

\begin{abstract}
ABSTRAK
Penelitian ini bertujuan untuk menyelidiki persepsi siswa terhadap plagiarisme, alasan siswa untuk melakukan plagiarisme dan cara siswa untuk menghindari plagiarisme di Universitas khususnya Bali Utara. Penelitian ini menggunakan metode campuran sekuensial eksplanatif dengan 175 siswa dari berbagai departemen dan fakultas. Data penelitian ini dikumpulkan melalui kuesioner dan wawancara. Kuesioner terdiri dari 30 item pernyataan tentang konsep plagiarisme, pengalaman siswa pada jenis plagiarisme, alasan siswa melakukan plagiarisme dan cara siswa untuk menghindari plagiarisme. Data penelitian ini dianalisis secara kuantitatif dan menunjukkan bahwa rata-rata persepsi mahasiswa terhadap plagiarisme adalah 3.9981 yang masuk dalam rentangan $3.69665 \leq \mathrm{M} \geq 4.64995$. Berdasarkan dari kualifikasi level dari rata-rata persepsi mahasiswa terhadap mahasiswa dikategorikan tinggi dan kualifikasinya positive. Berarti siswa memahami tentang plagiarisme dengan baik. Maka dapat disimpulkan bahwa mahasiswa mengerti tentang plagiarisme. Dari hasil tersebut, siswa diharapkan untuk menghindari plagiarisme dalam menyelesaikan tugas apapun. Untuk penelitian lebih lanjut disarankan melakukan penelitian yang serupa dengan peserta yang lebih besar.
\end{abstract}

Kata kunci: persepsi, plagiarisme, mahasiswa.

\begin{abstract}
This study aimed to investigate students' perception toward plagiarism, students' reasons to commit plagiarism and students' ways to avoid plagiarism in University in North Bali. This study employed explanatory sequential mixed method with 175 students from different departments and faculties. This data were collected questionnaire and interview. The questionnaire consisted of 30 items statements about plagiarism, students' experiences about plagiarism, students' reasons to commit plagiarism and students' ways to avoid plagiarism. This data were analyzed quantitatively. The result of this study showed score of students' perception toward plagiarism was 3.9981 in interval 3.69665 $\leq \mathrm{M} \geq 4.64995$. Based on qualification level, the score of students' perception toward plagiarism categorized high and the qualification was positive. It means the students' understand about plagiarism. It can be concluded students understand about plagiarism and the result students are expected to avoid plagiarism no matter. For further research it suggested to conduct similar study with larger participants.
\end{abstract}

Keywords: perception, plagiarism, University students.

\section{INTRODUCTION}

In every university, students are requiring to learn about doing scientific writing. As state by Perk (2015), scientific writing is a skill which can be started by reading, writing and then revising the work that must be trained by students during their bachelor program. 
According to Sun (2013), in scientific writing the writer is required to put appropriate credit like citation and reference of the sources of the information. It can be said that scientific writing is skill of writing that involve of several requirements to be followed.

It cannot be denied that in doing scientific work, the writers are using someone's argument, opinion or result of study to support their writing. Neville (2007), states that in taking advantages of someone's work in example theory, it is require for the writers to give acknowledgement of the original authors, but the failed acknowledgement could consider the writer to commit plagiarism. It means that giving acknowledgement of the original author that the work is use not only becomes the requirement in scientific writing, but it can help the writer to commit plagiarism.

According to Rampolla (2004), plagiarism is the action of taking someone's argument, ideas, opinion or word without giving a credit of the original authors. It is also defined as an act of using a work that belong to someone as a property and not giving the original owner credit of the job (Colnerud \& Rosander, 2009; Fish \& Hura, 2013). It can be categorized that plagiarism is the action of stealing someone's work without appreciate the original authors of the works which is harmful.

As states by Azher (2014), deliberate plagiarism can raise a serious consequence. As the Minister Regulation number 17 year 2010 by The government of Indonesia which set several consequences for students who are caught committing plagiarism such as give a warning, the postponement of granting of students' right, score cancellation, the honorable and dishonorable dismissal by institution to the students as plagiarist and the tittles cancellation. Thus, it can be said that those sanctions have can to remind students that plagiarism is risky actions to be conducted which can harm many parties. As states by Kalani and Twinwal (2013) that the harm of plagiarism also could influence the reputation of institution. It means that plagiarism not only harm the suspect but it could influences many parties.

According to Morrison (2015), plagiarism is categorized into two types namely unintentional plagiarism which involves of plagiarism that appeared when students' poor ability in citing, paraphrasing and quoting the information and then intentional plagiarism which involves of word plagiarism, structural plagiarism, style plagiarism, metaphors plagiarism, author plagiarism and self plagiarism. Weber-Wulff (2014) divided plagiarism into eight types of plagiarism such as copy-paste, shake and paste, mosaic plagiarism, translations, prawn sacrifice, structural plagiarism, partial reuse and self-plagiarism. It can be said that plagiarism is the actions which can be done by various ways.

Not only that, plagiarism also the actions which appeared due to various reasons. As states by Bahadori, Izadi, and Hoseinpourfard (2012), there are several reasons of students committing plagiarism such as students' lack of understanding, teachers' attention, great grade, temptation and opportunities, students' time management, students' attitude, denial of their own self, and lack of deterrence. Klein (2011), states that students will commit plagiarism because the lack of institution's policy. Poor language proficiency, poor of writing skill, the weak of educational background about scientific writing and unawareness of the consequence of plagiarism (Amsberry, 2009; Bakhtiyari et al., 2014; Guraya \& Guraya, 2017). It can be said that there are various factors that have potential influence students to commit plagiarism which can be from students' personal problem or students' environments. However, no matter what the reasons that influences student to commit plagiarism, that actions is still unacceptable to be conducted. 
As found by Murtaza, Zafar, Bashir, and Hussain (2013) that time management is one of theirs subjects' reason to commit plagiarism. Meanwhile, Prihantini and Indudewi (2016) found that one of the reasons students to commit plagiarism because they do not know how to cite sources from the internet and other sources. Thus it can be said that plagiarism can be done by various ways and influences by various factors.

From that case, before conducting this study the researchers conducted preliminary observation where the result of that observation was use as the foundation of conducting this study. Based on preliminary observation, it was found that some of students had committing plagiarism during their study. From that result the researchers conducting this study intended to investigate university students' perception toward plagiarism where the result of this study used as reflection of what institution or lecturers do next to reduce plagiarism case happens among students.

This study was conducted in one Univesity in Singaraja Bali namely Univesitas Pendidikan Ganesha (UNDIKSHA). The participants were 175 students of university that comes from each faculty which consist in Universitas Pendidikan Ganesha. The participants of this study were choosing by use purposive sampling. They are students who already passed or facing courses that require them to do scientific writing in example essay, research methodology, proposal and thesis.

\section{RESEARCH METHOD}

This study was quantitative study which used plagiarism perception questionnaire as the instrument of the current study. The questionnaire of this study was developed through four dimensions such as concept of plagiarism, students' experiences on types of plagiarism, students' reasons to commit plagiarism and students' experiences on the ways to avoid plagiarism. It was consist of 30 item statements which shared by used electronic questionnaire.

The result of this study was analyze by calculate the means score of university students' perception toward plagiarism. Mean is used to describe the arithmetic score average which becomes the calculation of central tendency that is commonly used and standard deviation is used to measure the dispersion of scores in distribution. In this study, the researcher used the guideline of qualification level by Koyan (2012) which can be seen in Table 1.

Table 1 Guideline of Qualification Level 


\begin{tabular}{|c|c|c|c|}
\hline No. & Interval & Categorization & Qualification \\
\hline 1. & $\begin{array}{l}\mathrm{Mi}+1.5 \text { Spi }<\mathrm{M}<\mathrm{Mi}+ \\
3.0 \mathrm{SDi}\end{array}$ & Very High & Very positive \\
\hline 2. & $\begin{array}{l}\mathrm{Mi}+0.5 \text { SDi } \mathrm{M}<\mathrm{Mi}+ \\
1.5 \mathrm{SDi}_{\mathrm{N}}\end{array}$ & High & Positive \\
\hline 3. & $\begin{array}{l}\mathrm{Mi}-0.5 \mathrm{SDi}<\mathrm{M}<\mathrm{Mi}+ \\
0.5 \mathrm{~S} \mathrm{Di}\end{array}$ & Average & Neutral \\
\hline 4 & $\begin{array}{l}\text { Mi - } 1.5 \text { SDikM< Mi - } \\
0.5 \mathrm{SD}_{\mathrm{j}}\end{array}$ & Low & Negative \\
\hline 5 & $\begin{array}{l}\text { Mi - 3.0 SDi }<X X<M i- \\
1.5 \text { SDi }^{-}\end{array}$ & Very low & Very Negative \\
\hline
\end{tabular}

(Adopted from Koyan, 2012, pp. 24-25)

From the Table 1, the researchers find out the level and the qualifications of the mean scores of questionnaire.

\section{FINDINGS AND DISCUSSION}

Based on the result of questionnaire, majority of students were aware and understand about plagiarism. It can be seen from the result of questionnaire in Diagram 1.

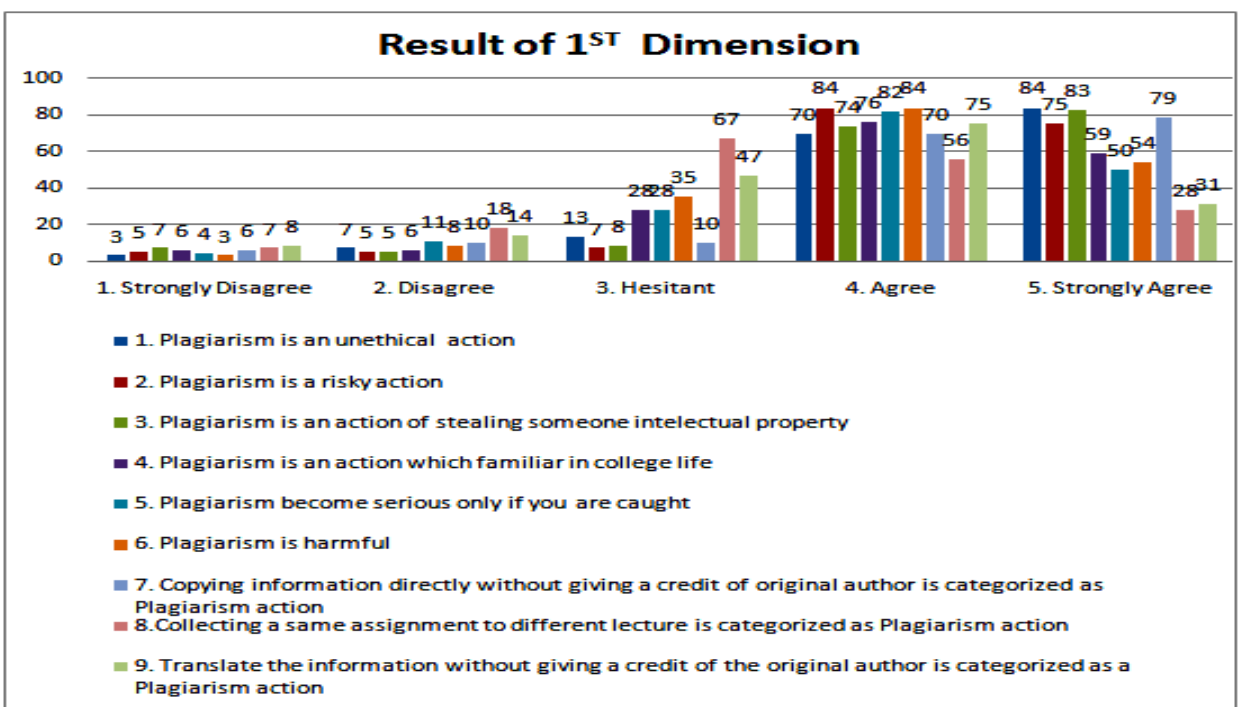

Diagram 1 Result of Plagiarism Perception Questionnaire on Concept of Plagiarism

Based on Diagram 1, it was found that majority of the participant (154 or $88 \%$ ) agreed that plagiarism is an unethical action. According to Wan, Wan, Hasbah and Tien (2015), plagiarism is an unethical act that must be eradicated from the students' mindset. Michalska (2014) also found that most of the participants that have been interviewed stated that plagiarism 
were wrong and ethical. From that result, it can be indicated that university students' understand about plagiarism.

Majority of the participant (89 or $50.9 \%$ ) also agreed that plagiarism is risky action. As can be seen, the government of Indonesia already set the sanctions of plagiarism in the Minister Regulation number 17 year 2010. The sanction includes (1) warning, (2) Postponement of granting of students' right, (3) Score Cancellation the value/score that already gave to the students, (4) dismissal and (5) Title cancellation. From that result it can be indicated that university students aware and understand about the risk of plagiarism.

Majority of participants (157 or $89.7 \%$ ) agreed that plagiarism is stealing someone's intellectual property. In line with Jones (2011), he stated that stealing unwritten ideas and concept or written such as text, note, material, design and others is categorized as plagiarism. Michalska (2014) also reported most of participants stated that plagiarism is stealing someone's work and make it ours. In other word, plagiarism can be done by several actions. It can be indicated that university students' understand about plagiarism.

Majority of the participants (135 or $77.1 \%$ ) agreed that plagiarism is a familiar action in college life. As stated by Kalani and Twinwal (2013), plagiarism is quite common in schools but it is seldom identified and punished. It cannot be denied that plagiarism already wide spreading even in college world because the ease of technology which makes students easier to commit plagiarism. The students think plagiarism is very common because they have unclear perception on what actually constitute plagiarism (Fish \& Hura, 2013). Thus, it can be indicated that plagiarism case is already wide spreading among university students.

Majority of the participant (132 or $74.6 \%$ ) agreed that plagiarism becomes serious only if they are caught. As mentioned by Bahadori, Izadi, and Hoseinpourfard (2012) one of the reason students to commit plagiarism because they denial. Even they already know that plagiarism is prohibited but they are still committing it. Kokkinaki et al. (2015), it was found that $57 \%$ of participants admitted that they commit plagiarism because they think that they will not be caught. From that result, it can be indicated that there are potential students committing plagiarism during their study.

Majority of the participant (138 or $79.3 \%$ ) agreed that plagiarism is harmful. According to Ali, Ismail, and Cheat (2012), the harm of the consequences of committing plagiarism not only feel by plagiarist but it also influence institution's reputation. It can be said that plagiarism can harm many parties and the result of this study can be indicated that students' aware and understand about plagiarism.

Majority of the participant (149 or $85.1 \%$ ) agreed that copying information directly without giving a credit of original author is categorized as plagiarism. As stated by Abukari (2016), copying someone word and regardless the credit or not giving acknowledgement of the owner of that work is categorized as plagiarism. Rezanejad and Rezaei (2013) also found that there were $81.1 \%$ of students equally agreed that copying information without put the credit is plagiarism. It can be said that university students understand and aware about plagiarism.

Majority of the participants (84 or $70.3 \%$ ) agreed that collecting a same assignment to different lecture is categorized as plagiarism action. As stated by Walker (2010) the reuse of 
work that have been submitted into a different purposes is categorized as a type of plagiarism action. It can be indicated that university students understand about plagiarism.

Majority of the participants (106 or $60.6 \%$ ) also agreed that translate the information without giving a credit of the original author is categorized as plagiarism action. As mentioned by Weber-Wulff (2014), translate the information from one language into another language is categorized as translation plagiarism. As found in the result of previous study, most of students in the previous study also aware that translation is considered as plagiarism (Ellis, 2012; WeberWulff, 2014). From the result of this study it can be indicated that university students' understand about plagiarism.

Based on that result of questionnaire, it was found that the mean score of that the Mean Ideal (Mi) of Plagiarism Perception Questionnaire on concept of plagiarism was 3.22 and the Standard Deviation Ideal (SDi) was 0.9533. Based on the criteria the means score was 3.9981 it was in interval $3.69665 \leq \mathrm{M} \geq 4.64995$.

Table 3. Mean Score of Students' Perception on Concept of Plagiarism

\begin{tabular}{|c|c|c|c|c|}
\hline No. & Criteria & Interval & Categorization & Qualification \\
\hline 1. & $\begin{array}{l}\mathrm{Mi}+1.5 \mathrm{SD}_{\mathrm{i}} \\
<\mathrm{M}<\mathrm{Mi}^{2}+3.0 \\
\mathrm{SD}_{\mathrm{i}}\end{array}$ & $\begin{array}{c}4.64995 \leqq \\
M \geq 6.0799\end{array}$ & Very High & Very positive \\
\hline 2. & $\begin{array}{l}\text { MPi } \\
\text { i. SDI }\end{array}$ & 3.696653 & High & Positive \\
\hline 3. & $\begin{array}{l}\mathrm{Mi}-0.5 \mathrm{SD}_{\mathrm{i}} \\
<\mathrm{M}<\mathrm{Mi}+0.5 \\
\mathrm{SD}_{\mathrm{i}}\end{array}$ & $\begin{array}{l}2.74335 \\
\leq \mathrm{M} \geq \\
3.69665\end{array}$ & Average & Neutral \\
\hline 4 & $\begin{array}{l}\mathrm{Mi}^{-}-1.5 \\
\mathrm{SD}_{\mathrm{i}}<\mathrm{M}^{-}<\mathrm{Mi}^{-}- \\
0.5 \text { SDi. }\end{array}$ & $\begin{array}{l}1.79005 \\
\leq \mathrm{M} \geq \\
2.74335\end{array}$ & Low & Negative \\
\hline 5 & $\begin{array}{l}\mathrm{Mi}_{-}-3.0 \mathrm{SD}_{\mathrm{i}} \\
<X<\mathrm{Mi}^{-1.5} \\
\mathrm{SD}_{\mathrm{i}}\end{array}$ & $\begin{array}{l}0.3601 \\
\leq \mathrm{M} \geq \\
1.79005\end{array}$ & Very low & Very Negative \\
\hline
\end{tabular}

(Adopted from Koyan, 2012, pp. 24-25)

Based on Table 3, it can be seen that the means score of university students' perception toward plagiarism was high and the qualification was positive. It means that university students were understood about plagiarism.

\section{CONCLUSION AND SUGGESTION}

Based on findings and discussion it can be concluded that students of Universitas Pendidikan Ganesha understand about plagiarism. The good result of this study is expected students to prevent themselves to commit plagiarism. From that result, students and also institution are suggested to maintain the good result of this study and improve the knowledge especially about plagiarism. For the further study, it is suggested to conduct a similar study which uses larger participants to make the result greater. 


\section{REFERENCES}

Amsberry, D. (2009). Deconstructing plagiarism: International students and textual borrowing practices. The Reference Librarian, 51(1), 31-44.

Azher, S. Z. (2014). Plagiarism: An academic crime. Advance Educational Institute \& Research Centre, 3.

Bahadori, M., Izadi, M., \& Hoseinpourfard, M. (2012). Plagiarism: Concepts, factors and solutions. Iranian Journal of Military Medicine, 14(3). https://doi.org/168-177

Bakhtiyari, K., Salehi, H., Embi, M., Shakiba, M., Zavvari, A., \& Shahbazi-Moghadam, M. (2014). Ethical and unethical methods of plagiarism prevention in academic writing. Inter Educ Stud, 7, 5262.

Brant, J. M., Haas-Haseman, M. L., Wei, S. H., Wickham, R., \& Ponto, J. (2015). Understanding and evaluating survey research. Journal of the Advanced Practitioner in Oncology, 6(2), 168-71. Retrieved from http://www.ncbi.nlm.nih.gov/pubmed/26649250

Colnerud, G., \& Rosander, M. (2009). Academic dishonesty, ethical norms, and learning. Assessment and Evaluation in Higher Education, 34(5).

Dansinger, M. (2017). Dear plagiarist: A letter to a peer reviewer who stole and published our manuscript as his own. Annals of Internal Medicine, 166(2), 143. https://doi.org/10.7326/M16-2551

Elander, J., Pittam, G., Lusher, J., Fox, P., \& Payne, N. (2010). Evaluation of an intervention to help students avoid unintentional plagiarism by improving their authorial identity. Assessment \& Evaluation in Higher Education, 28(May), 1-5. https://doi.org/35(2), 157-171

Ellis, C. (2012). Streamlining plagiarism detection: The role of electronic assessment management. International Journal for Educational Integrity, 8(2), 46-56.

Fish, R., \& Hura, G. (2013). Students ' perceptions of plagiarism. Journal of the Scholarship of Teaching and Learning, 13(5), 33-45.

Guraya, S. Y., \& Guraya, S. S. (2017). The confounding factors leading to plagiarism in academic writing and some suggested remedies: A systematic review. Journal of the Pakistan Medical Association, 67(5), 767-772.

Kalani, V., \& Twinwal, A. (2013). Plagiarism and its consequences, 2-4.

Kennedy, I. . (2006). How can I be original? In how to do research.

Klein, D. (2011). Why learners choose plagiarism : A review of literature. Interdisciplinary Journal of Knowledge and Learning Objects, 7, 97-110.

Kokkinaki, A. I., Demoliou, C., \& lakovidou, M. (2015). Students' perceptions of plagiarism and relevant policies in Cyprus. International Journal for Educational Integrity, 11(1), 3. https://doi.org/10.1007/s40979-015-0001-7 
Koyan, I. W. (2012). Statistik Pendidikan Teknik Analisis Data Kualitatif. Singaraja: Undiksha Press.

Madkhali, M. M. (2017). Saudi students ' perception of plagiarism. Culminating Projects in English. Retrieved from http://repository.stcloudstate.edu/engl_etds/91\%0AThis

Michalska, A. (2014). European students' voices on plagiarism and academic practices. Ippheae, 111.

Morrison, S. (2015). Types of plagiarism: You can't avoid it if you don't know what it is. Retrieved from https://unplag.com/blog/types-ofplagiarism/

Murtaza, G., Zafar, S., Bashir, I., \& Hussain, I. (2013). Evaluation of student's perception and behavior. Acta Bioethica, 19,(1), 125-130.

Neville, C. (2007). The complete guide to referencing and avoiding plagiarism. New York: Open University Press. https://doi.org/978-0-335-26203-8

Perk, M. van der. (2015). A guide for scientific writing. Bachelor Earth Sciences, (April), 1-24.

Prihantini, F. N., \& Indudewi, D. (2016). Kesadaran dan perilaku plagiarisme dikalangan mahasiswa: Studi pada mahasiswa fakultas Ekonomi jurusan Akuntansi Universitas Semarang. Jurnal Dinamika Sosial Budaya, 18, 68-75.

Rampolla, M. L. (2004). A pocket guide to writing history (4th editio). New York - Boston: edford / St. Marin's bedfordstmartins.com. Retrieved from https://pols.uic.edu/docs/default-source/studentdocs/avoiding_plagerism.pdf?sfvrsn=2

Rezanejad, A., \& Rezaei, S. (2013). Academic dishonesty at Universities: The case of plagiarism among Iranian Language Students. Journal of Academic Ethics, 11(4), 275-295. https://doi.org/10.1007/s10805-013-9193-8

Sun, Y. C. (2013). Do journal authors plagiarize? Using plagiarism detection software to uncover matching text across disciplines. Journal of English for Academic Purposes, 12(4), 264-272. https://doi.org/10.1016/j.jeap.2013.07.002

Weber-Wulff, D. (2014). False feathers: A perspective on academic plagiarism (Springer-V). Berlin. Retrieved from https://books.google.co.id 